\title{
“A Perfect Heroine in Foreign Travel.” \\ Female Mobile Identities and Southern Italy in the 19th Century Non-feminist Periodical Press
}

\author{
Marcella Romeo \\ University of Palermo, Palermo, Italy
}

\begin{abstract}
This essay focuses on the interaction between the publication of female travel writing about the South of Italy in non-feminist 19th century British periodicals, and the circulation of a transgressive model of femininity centred on the concepts of mobility, vitality and visibility. The choice of Southern Italy, an anti-tourist destination that since the era of the Grand Tour had been considered dangerous for men, let alone for women, magnifies female heroic attitudes and contaminates female conventional domestic purity enhancing the concept of an unfixed female identity. The publication of a travelogue, a mostly non-fictional genre, on an innovative and reactive medium, was a manifest act of transgression with respect to fixed social order, which gave visibility and credibility to a different model of femininity, an anti-Angel icon. A new form of narration displays adventurous women able to cross the private sphere and to write/publish authentic accounts of their transitional experience in a public, male-dominated sphere.
\end{abstract}

Keywords: women travelogues, 19th century non-feminist periodicals, Southern Italy, visibility, mobility, anti-Angel icon

\section{Introduction}

Women's periodical writing, and periodical female travel writing in particular, has not received a fair amount of scholarly attention, if compared with other fields of study, and the wide range of material periodicals supply is often ignored. Although women travel writing is "a complex, varied and fluid area” (Saunders, 2014, p. 1) and truthfulness of travelogues is widely debated, the publication of a travelogue, "a predominantly (and presupposedly) non-fictional genre” (Borm, 2004, p. 19) about an experience "out of place” (Douglas, 2000, p. 53) in "a fundamentally provocative and reactive medium ... the most significant organ for disseminating knowledge, information and social attitudes” (Fraser, Green, \& Johnston, 2003, p. xi) had a central role in negotiating gender ideologies. Being socially and culturally recognised had always been one of the major challenges for women travel writers generally accused of "exaggeration or lying” (Mills, 1991, p. 108). Indeed, "the very experience of travel ipso facto, subverts gender ideology and the ethos of domesticity; it involved a

\footnotetext{
1 Anonymous (1852).

Marcella Romeo, Associate Professor, Department of Economics, Business and Statistics, University of Palermo.
} 
redefinition of the feminine space and sphere of action” (Melman, 1992, p. 17), since women were crossing the border of the private sphere, the archetypal economic, social and political space assigned to femininity, and enacting the "disorderly mobility inherent to the idea of travel" (Kuehn \& Smethurst, 2009, p. 2). Writing a travelogue, a genre embedded in reality and veracity, on a travel experience in a dangerous, contested place, and publishing it in a (non-feminist) periodical, ${ }^{2}$ a discoursive site where crucial economic, political and social issues were dialogically debated, subverted cultural conventions twice, since it entered what was considered materially and symbolically a man's land. A new form of authentic, unfixed narration, swinging between the objective and the subjective, which matched the rigid requirements of the periodical market demand, granted women travellers to have their travelogues publicly recognised as true, their experience as authentic, their identity as an anti-Angel icon.

\section{An Anti-tourist Destination: The Emancipatory Component of Travel}

Travelling in and writing about the South of Italy in a non-feminist periodical was for women writers more than a transgressive act: it was a social challenge, an act of daring, although over the century progress in technology and the new mode of travelling by steamers and trains had had a huge impact on how travellers and readers perceived Southern Italy, a region geographically and, above all, mentally placed on Europe’s periphery. These territories became faster to be reached physically but culturally they remained faraway, and Sicily and Calabria in particular, uncomfortable to visit because of underdeveloped infrastructure, and dangerous because of the phenomenon of "brigantaggio" widely debated in periodicals. The conditions of travelling for women had improved during the century, too; but although since the 1850s they have travelled alone more frequently, from a social and cultural point of view travel, and especially travelling alone in a difficult, peripheral place, for a woman was considered a degenerative act, "always implicat[ing] her in uneasy cultural positions not without repercussions of daring the public or another psychosocial space” (Selléi \& Waudby, 2011, p. 1).

Traditionally, Naples was the Southernmost stop of the Grand Tour, and a few travellers ventured to Pompei or Paestum, usually only for a brief excursion from the city. Although Sicily was considered as the core of Magna Graecia, whose myths and tradition seemed to be genetically intertwined with English culture and civilization, beyond Naples it was taken for granted that chaos, filthy conditions, brigandage, lack of roads and means of transportation, no proper inns and awful food prevailed. Still in the second half of the century, when organised and sightseeing tours in Southern Italy grew in popularity, Naples was viewed as a liminal city, "a fault line, conventional and imaginary perhaps, but symbolised by the looming presence of Vesuvius as the end of civilisation" (Ouditt, 2014, p. 41). At the same time, the South represented "one of nineteenth-century patriotic culture's most important funds of images of alterity” (Dickie, 1999, p. 10), a way for the rest of Italy to situate itself with respect to an Other forged as a space in which "totemic values [were] considered all but synonyms with the Italian nation” (Dickie, 1999, p. 1). These values were linked to the idea of the Other English had of their own colonies spread, in the 19th century, all over the world. Likewise, Southern Italy, especially Sicily and Calabria,

\footnotetext{
2 As Levine noted (1990), the establishment of feminist periodicals began in the late 1850s; although some of them were short-lived and had problems of maintaining circulation, they had founding role in voicing women's issues and in shaping and spreading new female identities. They had middle-class women as their main audience, consisting basically of feminists being difficult to involve a non-feminist readership.
} 
was perceived "as a place of illiteracy, superstition, and magic; of corruption, brigandage, and cannibalism; of pastoral beauty and tranquility admixed with dirt and disease; a cradle of Italian and European civilization ... vaguely, dangerously, alluring African or Oriental” (Dickie, 1999, p. 1). The more travellers approached the hot South, the more they could be contaminated by immorality and dirt, symbolically and materially; disorder, disease, and underdevelopment could threaten Englishness. ${ }^{3}$ But the Mediterranean regions were of great attraction for English travellers who searched for their alleged Greek roots and for the picturesque longing for untrodden places far from mass tourism, on the increase since the 1850s, although this meant to be ready to encounter primitivism.

Although Southern Italy was not an immediate menace to the ideals of Englishness, it was the embodiment of disorder and chaos, and choosing the South as a destination signified, especially for women, an extreme "bodily displacement" (Bohem, 2012, p. 86). The bacterial transmission of disease was a great 19th century discovery and concern, and dirt was considered equal to pathogeny and a condition of disorder, while care for hygiene and respect for conventions were equal to healthy bodily and mental conditions. Travel was for women “an anomalous event” (Bohem, 2012, p. 53), and travelling in the South meant to encounter barbarism and decay, to "cross some forbidden line, to develop some impure condition” (Bohem, 2012, p. 11), in a material and a metaphorical sense. A "venture beyond the confines of societies," (Douglas, 2000, p. 115) travelling in Southern Italy granted women writers the possibility to disrupt conventional patterns providing also the potentialities for new ones to be scripted and spread, and publication of that experience in non-feminist periodicals unfolds as an “exercise in individual freedom, both physical and intellectual” (Bijon \& Gâcon, 2009, p. 2), projecting onto reality the possibility for different, unfixed identities. Women were able to cross the private sphere: female fragile bodies, established by the separate-spheres ideology, susceptible to physical and emotional harm, were represented as prompt to action, contamination and danger, and displayed publicly as inclined and fit to adventure, invulnerable to harm or risk, ready to encounter uncivilized people and to undertake travelling in regions so far from British aseptic domesticity and advanced civilization. Female intellects were displayed publicly as able to write authentic accounts of their transitional experience in a public, male-dominated sphere. Such women, whose materiality prevails against the immateriality of the iconic Angel, could socially exist within public discourse, reshaping the distribution of authorial and gender power.

\section{Travel Writing, Travelogues and Periodicals}

Travel writing, as Saunders claimed, "cannot easily be compartmentalised” (2014, p. 2) and the question of recognising it as a genre is still under debate. Brisson and Schweizer identified travel writing "as a distinct genre" (2009, p. 4); Borm considered travel writing a "collective term" (2004, p. 13) which comprises a diverse range of textual forms, both predominantely fictional and non fictional whose main subject is travel, rather than a proper genre. This essay considers travel writing as a genre per se which played founding role in shaping discourses of identity/alterity, functioning “as an alter ego for Englishness” (Gikandi, 1996, p. 113), and reshaping, as a consequence, the distribution of power and knowledge, not only between hegemonic and subaltern/subjected

\footnotetext{
${ }^{3}$ As Gikandi noted, the ideals that define 19th century Englishness are: "patriarcal domestic space, a harmonious social order, and psychological restraint” (1996, p. 105); actually, by encountering the Other Englishness was contemporarily questioned and reinforced.
} 
countries but also between genders who, still in 19th century, had unequal access to travel, travel writing, and travel writing publications. Hill emphasized travel "as a dynamic mode of experiencing and ordering the world in 19th century” (2016, p. 1), a form of movement whose components are themselves unstable and fluid. Gomez and Gifford focussed on travel as a source "for problematizing understandings of space and boundaries" (2013, p. 1) and for assessing how experiences in transit affect the concept of private and public. As Brisson and Schweizer noted, "Spaces of travel are spaces of political agency" (2009, p. 1) closely related to the competiton of power and to the distribution of authority, and travel writing is deeply anchored in specific historical and political reference systems. In 19th century, travel was a crucial component of men's education and social success, a cultural public area the separate-spheres ideology assigned them and to which they only had socially legitimate access. The right they had to speak, to write and to publish about remote places and about their experience of mobility as travellers/men in unknown, difficult sites had a main role in voicing their gender/authorial authority. Since travel narratives "provide a site to reimagine oneself" (Johnson, 2014, p. 101), during the century travel came to be "increasingly seen as a source of empowerment to many of those women seeking to expand their horizon of knowledge and arena of agency” (Kato, 2013, p. 77) in a period when education, most of professions, and economic independence were still usually a forbidden territory for them.

A mostly non-fictional text, the travelogue is a hybrid, fluid discoursive space which shifts between different genres (autobiography, diary, letter, guidebook), and which may juxtapose fragments of texts different in tone, style, vocabulary, voice, subject. Saunders (2014) focuses on travelogues as heterogeneous texts in which mobility and loss of fixed points are enhanced. She points out how the private, authobiographical component facilitated women's access to travel writing, as a device to validate their accounts, and how truth "paradoxically, appears as both an assertion of 'masculine' objective rhetoric and the apparently, feminine 'authentic' utterance of ... 'feminine', domestic, private literature” (Saunders, 2014, p. 3). Accounts of travel written by women were usually considered misleading, caricatural texts, and therefore dismissed, and women travel writers were never considered on the same terms as their male counterparts. The cultural area assigned to them was the private sphere, and only texts embedded in the private sphere linked to their "natural" tendency towards immaginative and fanciful evocations could be socially and authorially acceptable. Female travelling was not socially acceptable, above all in dangerous, faraway places; it was immoral and socially censurable, and female travel writing was considered embedded in untruth and fantasy, the paradigmes opposite to what readers and editors expected in a travel account, when truth, authenticity and reliability were the essential criteria for travelogues to be published, especially in periodicals.

"This is the age of periodicals, and above all of cheap periodicals," (Tait, 1832, p. 784) the editor of Tait's Edinburgh Magazine stressed in an interview. A genre per se, the Periodical was an innovative, interdisciplinary and dialogic site that exerted cultural power matching readers' "desire to keep up with the world" (Altick, 1998, p. 318). "Immensely resilient and self-renewing” (Beetham, 1989, p. 97), it challenged the boundaries between conventional fields of knowledge and hierachies between them. Flexible and hybrid in itself, it aimed at amusing and instructing readers providing them with attractive, truthful and timely information. The more authentic and original the materials published, the more prestigious and in-formative the Periodical was. ${ }^{4}$ A huge amount of travelogues and reviews on travel books were published in 19th century periodicals, and travelogues may be

\footnotetext{
${ }^{4}$ For an insightful analysis on the discoursive nature of periodicals and their founding role in 19th century culture and society see, among others: Doughan and Sanchez (1987); Don Vann and VanArsdel (1994); Brake and Demoor (2011).
} 
considered the "dominant social text" (Gikandi, 1996, p. 97). Victorian culture was provided with by colonialist culture. In the period when both colonisation and the necessity for education reached their climax, travel produced knowledge which was used both to justify hegemony on territories and peoples, and to in-form middle-class and working-class readers. Their appetite for accounts of travel was continuously on the increase as well as their ability to recognize un-faithful stories. Editors were highly motivated/pressed by this market demand, both for economic reasons and because they were aware of the importance periodicals had in shaping readers' opinion, compared to novels or romances, more expensive and subjected to the restrictions of circulating libraries and reading clubs. This cultural climate led to the urgency to match quantity and quality of travelogues:

Appetite for accounts of travels has ... certainly not diminished as the world had advanced in years: only we desire nowadays not only to be informed, but to be plainly and accurately informed concerning things which may touch us so nearly... The traveler's license is rescinded. We not only do not allow him to take the liberty with facts, but we tolerate no fanciful colouring for the sake of sensation or expansion; still less do we allow of perplexing and marring what should be a clear, simple and honest description, with tedious disquisitions, tumid representations and irrelevant pedantry. (Grant, 1872, p. 691)

Periodical press required honest, authentic, precise descriptions; neither fanciful misrepresentations, nor involute linguistic or thematic exaggerations were allowed. The 19th century periodical travel discoursive market asked for truth, and the publication of a woman travelogue in a non-feminist periodical meant to assume the responsibility to convey readers' truthful information.

The travelogues analysed show a plain, straightforward narration, free from redundant descriptions or historical and philosophical digressions, free from ambiguities and easy to understand. They are marked by a moderate usage of pre-modifiers, metaphors and similes, and the subjective/objective dimension is strategically balanced all through the narrations as for people met and landscapes discovered. Desire for mobility and vitality prevails in transfers between destinations, a natural sense of self-humour and irony in disagreeable situations, courage, bravery and curiosity in dangerous and risky conditions, pragmatism in odd circumstances. There is no self-censorship, no conquering aspiration, no missionary or educational aim. Rather, travel experiences are focused on personal discovery, on exploration of a liminal destination, and on pleasure. Authors do not apologize (as they used to do especially in early century travel writing) for unsophisticated writing, insisting on the authenticity of their accounts, stressing how they wrote things in the exact order in which they occurred, and above all on their deliberate choice to experience a non-tourist, difficult destination. Possible digressions and lack of sophistication of the form seem to be designed to make the content more truthful and genuine.

In experiencing a wild, dangerous location like Southern Italy, women travellers are partially affected by prevailing discourses of Orientalism; they embrace some of the stereotypes of their time but it is apparent that they are ready to re-negotiate them. They appropriate adventurous tropes, without fictionalising themselves as characters into the narration, and without being "at pains to claim ... male authority for their narratives" (Hill, 2016, p. 2), spreading the image of the anti-Angel icon as a socially and culturally acceptable woman, able to transcend the "assumed authenticity" (Saunders, 2014, p. 1) of men travelogues. This new form of narration, with its plain, captivating rhetoric claiming for veracity, shapes and conveys new female identity trajectories able to cover a great cultural distance, and to revise the tradition of heroism. "Cultural contact, travel, and mobility open up hidden links ... generating new configurations of identity in formerly uniform spaces” (Arapoglou, Fodor, \& 
Nyman, 2014, p. 3); and the travelogues analysed advocate and help establish "perfect heroines in foreign travel" (Anonymous, 1852, p. 69) who travel both for pleasure and knowledge, who explore and observe without the urgency to subject or conquer, who situate themselves as authorial original voices also in travel writing.

\section{Female Journeys and Southern Italy: Untrodden Identities in Motion}

"Periodical pages are microscopic opportunities inviting us to examine textual artefacts that aid in understanding women's lives during the period” (Ledbetter, 2009, p. 9). The travelogues analysed are drawn from Temple Bar, The National Review (monthly journals), The Kaleidoscope, considered the first cheap weekly miscellany, and To-day (weekly journals), all aimed at a middle-class readership. ${ }^{5}$ Kaleidoscope introduces "Letters from a Lady Abroad to her Friends at Home" (1827) with a note, "Sicily”, emphasizing the importance of the travelogue that, despite being written by a female, as immediately specified by editors, should be taken as an example by readers invited to do what "she has more than once set ... noting down anything particular in their 'journey through life' allowing the public to participate, mentally at least, in their pleasures” (Anonymous, 1827a, p. 325). In a further note the author's mother supports the publication of her daughter's travelogue for its "beauty, brilliancy and endless variety” (p. 325), juxtaposing two female generations: hers, still devoted to domesticity which had always written "more for fun than anything else" (p. 325), and the new generation, which is allowed and able to write "a brilliant bit of glass to sparkle in Kaleidoscope" (p. 325) professionally, to share travel experiences and pleasure with readers, to inform them truthfully about distant and dangerous places like Sicily. Initially the traveller apologizes for having given "a very imperfect description of what occurred on our voyage ... written amidst the hurry ... to a first arrival in a strange country” (p. 325), considered one of the most dangerous in Europe, but only to set the parameters of her own writing. The editors view her letters as extremely correct in style, as if "intended to be printed" (p. 325), suggesting writing was something natural for her, while it was mostly viewed as something unnatural for women, let alone writing about their travel experience in inappropriate places. Then, decades before Virginia Woolf (1928) declared the necessity for women writers to arrange a new sentence, the anonymous traveller sets her own style, her own sentence and contents:

I will try to write with some degree of accuracy, and give you as correct a notion of what I see in this country as I possibly can. But you must permit me to express what I have to communicate in my own way, freely, and, if you please, carelessly. (p. 325)

Her travelogues will be not "learned epistles" (p. 325), "tedious disquisitions", but a source of straightforward information since she was "too busily occupied with sights, scenes, characters, and customs ... entirely new ... to sit coolly down and philosophize upon any subject” (p. 325), conveying the idea of a woman positively overwhelmed with new hints whose richness deserves all her perceptive capacities to be effectively conveyed to readers without "irrelevant pedantry". She appears ready to encounter the Other straightforwardly, and to inform readers in the most vivid way by referring "everything in the order it occurs” (p. 326); the text, thus, is rich of what may seem digressions that make the recollection realistic and colourful. The usage of the pronoun "I" prevails testifying how the traveller, despite anonymity, is not afraid of proving her personality to be assertive

\footnotetext{
${ }^{5}$ Authorship of unsigned travelogues has been attributed by reference to The Wellesley Index to British Periodicals. "Letters from a Lady Abroad to her Friends at Home" remains anonymous.
} 
in claiming her rights to travel, and to write about her travel in a difficult country also for pleasure. She is based in Palermo and she is travelling with a group of friends and her husband.

The traveller introduces her body and spirit as mobile entities; together with Mr Montgomery, she says, "we are the only two in the party who preferred walking to sleeping” (p. 326), fixing a female identity closer to mannish attitudes than to the other ladies of the party, a woman full of energy and extremely active, who prefers physical mobility to bodily stability and who is willing to participate directly to events. She undertakes the trip to Segesta although they cannot use the house of Barone Pastori any longer, proving herself ready to face the very well-known discomfort of Sicilian local inns, "in every sense of the word, intolerably bad, and always scantily provided” (p. 326). Leaving from Palermo she welcomes coaches that had three horses abreast, although she "was forcibly struck with the oddity of their appearance" (p. 326), and she accepts the "invariable rule in Palermo always to separate husbands and wives in parties of pleasure" (p. 326), informing readers explicitly on the reason of the excursion emphasised by her italics. She shows her boldness in crossing the mountains to reach Partinico, "we were now on the edge of an immense precipice; my heart turned cold as I cast my eyes on the chasm below ... I shuddered with apprehension ... what an excellent haunt for banditti” (p. 326), and the torrid Sicilian climatic conditions do not prevent her from continuing her journey: "The heat of the sun was more oppressive than we have previously found it; the roads being covered with thick dust ... which reflected both light and heat to such a degree that travelling became very unpleasant” (Anonymous, 1827b, p. 333). The traveller is also prompt in facing a seemingly unpleasant situation at her arrival in Alcamo where they "found shocking roads and worse inns" (p. 333). The description of the inn and of the people attending the place clearly sets a huge distance between the traveller and the reality experienced: a white female belonging to the most civilised country in the world vs. a landlady "whose youth and beauty would have qualified her to rank with the weird sisters of Macbeth” (p. 333). She is welcomed by this woman accompanied by "a dirty black pig and some half-starved poultry" (p. 333), conveying the idea that proximity between people and animals was the rule, and by a pervasive "stench of garlic [and] a hundred other stenches commingled, [they] would gladly have been without" (p. 333). The place and the situation suggest uncleanness and contamination that, when it comes to food, the traveller is not completely ready to share: "Our own servants were employed in this useful business, or, hungry as I was, I think I could not have eaten anything from hands of these unclean creatures” (p. 333). Yet, uncleanness has no ethical connotation, it is only something physically undesirable and unpleasant which she faces with irony, ${ }^{6}$ the same attitude she unfolds when describing her cavalcade from Alcamo to Segesta, in which "men, women, and children, with pigs and goats in abundance” (p. 333) welcome and follow them.

Following the paradigms of the picturesque, she is attracted by landscape which gives her the opportunity to sketch, "on every side such a variety of scenes of sublimity and beauty” (Anonymous, 1827a, p. 326), although she ironically quotes William Combe's poem The Three Tours of Dr Syntax, a comic work satirizing picturesque ethics. Landscape is altogether orientalised in its overwhelming fascination belonging to an unfamiliar world and compared to a paradise saturated with amazing beauties, which have the ability of regenerating: "The morning air was sweet and balmy; our spirits were revived by its freshness, and the sun was rising in all his glory; not a cloud to interrupt his beauties, and all around us ... looked like a paradise” (Anonymous, 1827b, p. 333).

\footnotetext{
${ }^{6}$ In all the travelogues irony sometimes seems to be a dialectical device "that simultaneously questions and affirms Englishness" (Gikandi, 1996, p. 96).
} 
Local people are mocked since they venerate too many saints who, "far from be rare commodities, are almost as plentiful as blackberries” (Anonymous, 1827a, p. 325), disapproved as they seem to be possessed by a foolish passion for them, so that they "would sooner deprive themselves of bread than the Virgin of her wax candles" (p. 326), and criticized since "they may live in dirt, steal their neighbours' goods, and be absolutely unreliable on every occasion in daily life, but so many 'Aves' and Credos' must be said” (p. 542). Although they never have a voice, they play music and sing "giving life and beauty to the scene” (p. 326). The quintessence of contrast and fascination is expressed when describing the music played by Sicilian pipes: "There is a sweetness and a wildness in this simple instrument ... beyond anything I have ever heard ... they warble according to the feelings of the moment ... breathing into their pipes all the feelings of the heart” (p. 326). Music synthesizes the author's attitude on Sicily: opposites, which are never resolved, like pleasing and unpleasant, attractive and repulsive forge a place whose identity is based on conflicts that include all the possible shades of the human feelings crossing each other with the most unpredictable enchanting irregularity.

Interestingly, physical effort in crossing Sicily has on the traveller a reverse effect generally exertion had on her in England; it is generative, giving origin to a different woman, marked by a great physical power, in good health, resistant to unpleasant circumstances, an anti-Angel:

Rising at four o’clock each morning ... under the influence of a Sicilian sun ... I had never two harder days work in my life. Extreme fatigue often prevents me sleeping; but such was not the case ... next morning ... I was quite well; not even an ache, or pain, or anything to complain of. (Anonymous, 1827b, p. 350)

"Taormina” (1876) is published unsigned in the Temple Bar; readers are introduced in medias res and presented with the traveller as an adventurous woman aspiring to mobility, resolute in approaching an anti-tourist destination by vitality and curiosity, and determined to reach Taormina "in the teeth of the wind and rain" (Kennard, 1876, p. 539). By a very old train they arrive at the beach and the influence it has on the traveller is impressive: "It was impossible to resist the temptation of strolling down ... to try and get rid of the jar and discord of the 'Great Civiliser'” (p. 539). Identity can be overturned, the sea, the sand and the hypnotizing flow of the water allow the traveller to dream to launch herself into the uncontrolled borders of uncivilized worlds, to change her skin, although she "could not allow dreaming, however pleasant" (p. 540), belonging to the most civilized race in the world. The possibility Sicily gives to make a journey in the glorious past of Greek civilization leads Kennard to set a sharp contrast between the active, magnificent past and the lazy, dead present. Taormina now "looks like a town asleep, a beautiful dream ... the people seem to have lost all hope, they have fulfilled their destiny" (p. 541); men cultivate the earth very industriously but with tools "as rude as those ancestors used at the time Virgil's Eclogues were written” (p. 541), and the train, "makes no difference in their lives; they only gaze dreamily at its trail of white smoke across the valley; and know it is 'mezzogiorno'” (p. 542). Kennard establishes a huge distance between England and Sicily due to technological and social development appreciating the positive aspects of progress but also how underdevelopment has left Sicilian nature intact, revealing her nostalgic attitude towards pre-industrial England: "A little silver stream, which in England would have been made to turn a paper or cotton mill ... here took its way down the hill ... charming our ears by its music” (p. 542). Also local people prompt unfixed inclinations, "The Sicilian of to-day, however degenerate he may be, cannot forswear his descent. There is Greek grace in many of the girlish figures ... eastern picturesqueness in the old hag hobbling up 
the street” (p. 542). Degenerate is an unambiguous connotation that aligns Sicilians with people whose mental and physical level is lower than normal standard but Greek grace and also oriental oddness may be traced in their looks. Brigandage is described as something innate in Sicily; Keppel does not feel threatened but she is aware that it is a plague on one of the most fascinating isles in the world: "Fair and fruitful Sicily! ...you would indeed be an 'Islands of the Blest', had not man brought a curse on you, and by injustice and wickedness made your name a byword among civilized nations!” (1893, p. 544). Although she is not obsessively in search for the picturesque, the luxuriant nature and the kaleidoscopic mixture of colours are emphasised and often the traveller dwells on the conflicting beauties of landscape: "The first half-mile of the ascent (to Taormina) lay between walls of loose stones ... but as we got higher the blue Mediterranean unrolled itself at our feet ... there was every gradation of colour round us, from tenderest grey to the most brilliant green” (p. 540). Sicily is characterized by a perpetual disharmony between its magnificent, irregular landscape and the people, inevitably linked to a glorious past, but blocked in a dull, immobile present that leaves them out of history. Kennard identifies herself as a traveller in a world where mass tourism was almost the rule, reinforcing the anti-tourist component of her journey, when a “dreadful voice, harsh and discordant ... the 'custode' of the place, heading a band of American sightseers” (p. 545), abruptly interrupts her contemplation of the view from the Greek Theatre.

Elizabeth Lynn Linton signs her travelogues published on Temple Bar and To-day. "Bronte on Mount Etna" (1884a) opens in medias res overwhelming the reader with the description of Palermo, a sort of earthly Eden, wrapped by the scirocco, a "serpent which makes its fairest fruits but dust and bitterness" (1884a, p. 229). The alliteration boosts the oppressive atmosphere hypnotizing readers in its suffocating waves of inflamed wind, justifying Linton's journey to eastern Sicily “to breathe freely once more” (p. 229). Sicilian roads are altogether criticized since "the comfort or convenience of travellers is the last consideration that troubles the administration" (p. 229), although they are generally made alive by “files of men and women travelling” (p. 229). Discomfort and unsafety are never emphasised, and the guard at the Castello Maniace armed with a gun and a revolver is considered "a matter of precaution rather than of actual need; the country being nominally quiet, but ... practically untrustworthy" (p. 230); interestingly for a woman, she claims that "it is better to be on the safe side and to have a few ounces of lead to dispose of" (p. 230).

Linton is not obsessed with the search for picturesque, although "magnificent points of view ... picturesque bits of skyline and framework" (p. 230) are often quoted in the text, and she is deeply moved by some perspectives which boost the kaleidoscope of colours, the luxuriant nature and the power of sunshine: "A narrow gorge of overhanging rocks thickly covered with flowers and trees and trailing growths of every kind ... a bounding line of purple mountain; and such a sky as one gets only in Sicily” (p. 238). Sicilian landscape is characterized by irresolvable opposites, bright colours, vibrant sonorities, and a wild nature; yet, it is never alarming, conveying positive energy to the traveller allowing her to forget exposure to risk and to abandon usual scansion of time: "All this colour and fragrance-roses and violets ... make us forget that this is now really November; that we are two thousand feet above the level of the sea; that Etna is covered with snow; and that in the true winter wolves come down to devour the flocks” (p. 239). The pervasive beauty of landscape introduces the power Sicilian sunshine has to transfigure every ugliness into something pleasurable to the senses, "what a magician that sunshine is! ...near at hand we should see only dirt and crudity; touched by the sun we have colour and harmony which the looms of India itself could not match!” (p. 237) 
Glorious landscapes, however, seem to be designed to augment the hideousness of people who inhabit them; passing at a fountain where some women were washing she wonders: "Are they men or women? so hideous, coarsened and unsexed are they" (p. 238). The "grape-gatherers bearing their basket full of shining fruits" (p. 230) remind Linton of the Greek myth of Dionysus and the glory of a past that has definitely abandoned Sicily:

Those grape-gatherers of to-day, ragged, dirty, poverty-stricken, weary, are very little like the traditional fauns and bacchantes of the past. They are not even beautiful; though sometimes you see a face ... which, if clean, would be enchanting; but for the most part the men look like brigands and the women are repulsive hags. (p. 230)

This is a synecdoche exemplifying Linton's perception of Sicily as being in a median stage of civilization. It is not unintentionally that Linton concludes her travelogue by comparing Sicily to an Oriental locus that typically "threatened hygiene and domestic seemliness" (Said, 1995, p. 166). Yet, she does not feel to be menaced by her bodily displacement and her choice of an anti-tourist destination reinforces domestic purity and racial superiority enhancing, however, her capacity, as a female traveller, to observe and analyse the isle objectively: "The air is heavy with the smell of wine; the ground is strewn with crushed grapes; the whole place is Bacchic, Eastern, unhomelike" (Linton, 1884a, p. 241). Although Linton embraces some prevailing oriental stereotypes, she also disrupts them by specifying how in that context "there is no licence, no disorder; all is done with order and method, and this gaiety helps ... the more serious question of work” (p. 241). Also the quotation of some curious Sicilian anecdotes is aimed at fixing Sicilian backwardness if compared to England: "Do not these extracts take us back almost centuries in our history?” (p. 237). She concludes by claiming, implicitly, that underdevelopment, uncleanness and poverty could be removed by the constant presence of the British technological progress, so to combine nature and culture: "And if ... Bronte wine is what it is, when carelessly made ... what if the valuable qualities given by nature are helped by the last improvements in science?” (p. 241).

An extended exordium introduces “The Things of Palermo" (1884b) in which Linton aims at setting a new border between Sicilian stereotypes and Sicilian reality, and also at establishing herself as a female traveller of moral strength and courage able to see and analyse an unfamiliar place in a "truly" objective way:

There is no place in Italy of which so much nonsense is talked as of Palermo. Fever and brigandage ... a society hopelessly immoral ... these are the outlines of that fancy picture which those who have never been there draw of Sicily in general and of Palermo in particular; and they ask you to believe in the accuracy of their delineation. (Linton, 1884b, p. 481)

The depiction of Sicily, allegedly authentic travel writing (basically male) has perpetrated as an unsafe place, is only a misconception, fruit of pure imagination that has misled readers. Linton disrupts the most conventional stereotypes about Sicily arousing the interest of the reader who expects implicitly a new, more accurate overview about the isle, its customs and its inhabitants. She sets herself as a reliable travel writer, despite being female, whose intention is telling the real truth about her experience with no exaggeration and lying. Instead of emphasising only negative aspects, Linton establishes a new agenda for travellers, an agenda which can be comfortably experienced also by women. Although it "requires some moral courage ... to believe that human nature must be much the same in Palermo as elsewhere; that Sicilian civilization is not different from Italian civilization on the whole” (p. 481), Linton destabilizes her readers by disempowering their illusory certainties about Sicily, reinforcing also the identity of a female traveller not easily influenced, who intends to share her 
experience in one of the most controversial destinations in the Mediterranean. She concludes by stressing a fundamental component generally ignored in female travel, since it was not allowed to women, "pleasure": "If you have moral strength enough to resist ... depressing influences, and to carry out your intention, you will add a new pleasure to your string of memories” (p. 481).

"Some Sicilian Customs" (1884c) is a commentary by Linton on some peculiar usages Pitrè describes in his work about Sicily supported by her direct observation. The tone is inclined to irony but never disrespectful, all the observations being centred on an unambiguous premise: Sicilians "are neither savages not yet blocked out into fair form ... still in that quasi-mythical and fetichistic state, when usages have a superstitious meaning beyond their social importance” (Linton, 1884c, p. 393). Sicily stays in a transition developmental stage, it has emerged from wildness but it is not thoroughly civilized yet; no precise indication of nationalities is given but it seems implicit that England represents the highest developmental stage in human race. Certainly it was not necessary for Linton to publish travelogues on a periodical to gain visibility; but it is what she writes about Sicily and the message conveyed about the ability women had to transcend alleged male veracity in travelogues and to transform their journeys to Southern Italy into a social challenge, and a source of pleasure which is the crucial point of her publications.

"Byeways in Sicily” (1893) is published signed in The National Review. From the beginning Keppel stresses her willingness "to leave the tourist's track and drive along the north coast of Sicily to Messina," (1893, p. 661) for which a special permission was necessary because of the unsafety of the area, setting adventure as the main objective of her journey: "Our Palermitan friends thought us foolhardy ... they shook their heads hinting at brigands and discomfort. We laughed at the thought of danger then; but recent accounts of brigandage ... retrospectively justify their friendly apprehension” (p. 661). She informs the reader she is not travelling alone, insisting on her determination to experience uncivilized and risky contexts. Keppel starts her journey by visiting the Monastery in Gibilmanna described as the locus of discomfort where only, "a raised wooden platform to sleep on and a wooden table and bench" (p. 661) is given to the ladies, and as the locus of unsafety, since the monks themselves "advised ... to bolt ... doors and windows and on no account to open them again" (p. 661). She reaches Santo Stefano "through wild scenery ... the most squalid village imaginable, peopled by haggard men and women and ragged children" (p. 663), Sant'Agata, where her "disgust was great ... besides the never-failing pasta, there was nothing in the house” (p. 663), and Patti, “dirty and uncivilized to the last degree” (p. 663). In Barcellona, however, she says, "fate, favouring, led us into an earthly paradise ... a lemon grove ... the fragrance of the blossoms, the peeps at distant sea and hills, sunlight and shadow chasing each other across the rich brown soil” (p. 665). Conflicting experiences mark Keppel's narration who insists on her familiarization with wildness stressed by the fact that only in Messina they "were carried back into civilized life” (p. 665), and by her emphasizing: "As I am concerned here merely with the byways of Sicily, I will carry my reader without delay to Maniace, Lord Bridport’s Sicilian property” (p. 665). The providential presence of the English in Sicily and how they made the country and the people more civilized is underlined. Readers are also informed on the domestic state of Sicilian peasantry and slowly introduced to Sicilian intrinsic oddity and backwardness, through the description of a "curious native dance" (p. 666), a synecdoche for that wilderness she was looking for but which she "watched from the dining-room windows" (p. 666) of the Castle, at a due distance: 
Only men took part in it ... there seemed to be no particular method in the weird and grotesque performance. The antics of the dancers were extraordinary. Brandishing a long lighted torch above their head, and from time to time uttering hideous screams, each man capered on his own account. (p. 666)

A breach of order and conventional canons, this frantic dance, a combination of bizarre movements performed in an impassioned manner, is suggestive of the supernatural and its incessant irregular and loud clamour impresses the traveller. She also gives interesting hints about the management of the estate and people working there. They "seem to work steadily as long as they are under surveillance ... in the morning they have a large chunk of bread ... in the evening they feed like animals ... they are dirty to a degree hardly conceivable ... their pigs live with them in close familiarity” (p. 666). Colonialist manicheism sometimes goes to its logical conclusion by dehumanising the native and "turns him into an animal" (Fanon, 1990, p. 31), and Keppel transfigures Sicilian peasants; she specifies repeatedly their proximity with pigs and dirt, stressing also how, altogether, Sicilians "do not seem to be an attractive race. They deceive on principle, and gratitude is to them an unknown quality” (Keppel, 1893, p. 667), revealing the imperialist connotation of her gaze. She dwells on the status of submission in which women are confined, obliged to combined marriages at the age of fifteen and considered so "unprofitable [that] in some parts of the island the advent of a baby girl is looked upon as such a misfortune that a small black flag is hung out of the window to proclaim the sad event” (p. 667); boys, instead, "are soon self-supporting and ... increase the family health" (p. 667). Descriptive categories are designed to distance herself from a wild, quaintly odd country totally remote, which she is observing and analysing, about which she is informing readers but with which she does not really interact. The travelogue concludes abruptly with a comment on Sicilian superstitious beliefs aiming at reinforcing both Sicilian perseverance in ignorance and irrationality, and the ideals of Englishness. Keppel is not interested in picturesque landscape descriptions although the time spent in the lemon grove is "one of the pleasantest of ... Sicilian memories,” (1893, p. 665) and the only sketch she gives about Sicilian territory.

From this perspective, late 19th century travelogues reveal a progressive decreasing interest in landscape depiction focussing on people's attitudes and characters. "Calabrian Sketches” (1897) published unsigned in Temple Bar, confirms this trend. The woman travels alone, the pronoun "I" is obsessively used, and she is based in Tropea, "one of the most aristocratic towns in Calabria” (Le Mesurier, 1897, p. 275). She does not insist either on the authenticity of her narration or in the adventurousness of her experiences; she dwells on the description of people's private and social behaviour, since her noble hostess "received visitors at home from six to ten o'clock in the evening" (p. 280), so she "studied the character and ways of the people" (p. 280), and on the pleasure she has in exploring untrodden paths.

Nobility in Calabria has decayed and education has no priority for them; women are "still more uneducated than men; they never open a book or even a newspaper ... many are hardly able to sign their names” (p. 280). Among them "there is a high standard of morality" (p. 280), and they "devote themselves to their children and to their household duties, and give little thought to pleasure” (p. 276), proved by their astonishment at her having a walk every day, which emphasises her distance from local women and her familiarity with pleasure: "I heard that they expressed surprise at my taking a daily walk, as most of them seldom leave the house except to go to church" (p. 276). Women from Calabria "although not naturally stupid, are strangely apathetic" (p. 281), and still imprisoned in their role of Angel, preys of a subcultural patriarchal system and of their own ignorance and 
laziness. Calabrian men are, "with the exception of the Sicilians, the most jealous in disposition, but they seldom have cause for it" (p. 276). Despite their ignorance, they are "exceedingly intelligent and eager for information; from the highest to the lowest they take an immense interest in politics" (p. 281). Altogether, people are "thrifty and industrious" (p. 281) despite having a "vindictive character" (p. 279), and generally they have "a predilection for foreigners, and delight in showing them every attention” (p. 276). A young noble man's death prompts Le Mesurier to comment on Calabrians more in detail, and to set a distance from them. Far from English bodily education given especially to men, this young man's "life at home had been a sedentary one ... and it was not to be wondered at if he broke down under the hard life of soldier" (p. 279). The reaction to death by parents and relatives astonishes the traveller, "Never shall I forget the day when the news reached ... the unfortunate family; their shrieks and cries were fearful ... grief was utterly uncontrolled; they rolled on the ground, and shrieked till their strength failed them" (p. 278); unexpectedly, she was the only one to be disoriented by the incapacity of controlling sorrow and emotions, "these ebullitions, when sorrow is deeply felt, being considered quite natural" (p. 278). The traveller, however, never makes explicit comparisons limiting herself to express her opinion on what she is observing.

The several excursions Le Mesurier does in the neighbouring area enhance her desire for mobility and lead her to describe charming views and luxuriant nature. Although she is not preoccupied with the search for picturesque, she derives aesthetic satisfaction from landscape: "Mount Etna could be clearly distinguished, with the wreath of fleecy white clouds which are always to be seen resting just beneath its cone. It seemed as if one could never gaze enough of this beauty" (p. 283). There is no urgency to fix the overall impression of the scene and landscape lets her activate unrestrained trajectories; coming out from the Chapel at l'Isola, she says, "we found the whole expanse of sky and sea tinged with gold from the glow of the setting sun; the Lipari Island ... stood out clear on the horizon, and we stayed to watch the sun dip into the sea just behind the island of Stromboli, from which a pale wrath of smoke was solely ascending” (p. 287).

Calabrian songs are "wild, plaintive, and full of pathos" (p. 283) and dancing is "exceedingly graceful, but rather slow and measured" (p. 283). Despite wildness, songs are mournful and dancing is not hectic, as one could expect in Southern Italy, and shows grace of movement, form and proportion. The day preceding her departure she "was quite overwhelmed by the presents sent by numerous friends" (p. 297), among which there was,

...a beautiful pointed dagger in a sheath, such as is unfortunately carried by most of the natives of Calabria, and often fatally used in their frequent quarrels. I was told to hide it carefully in my trunk, as such arms are strictly forbidden by the Government. (p. 288)

Although it is apparent she deplores the usage of such arms, surprisingly she decides to bring it with her. A “dark morning with a drizzling rain falling” (p. 288), marks her departure brightened by people and their "last good-byes ... said with warm and pressing invitation to return” (p. 288).

\section{Conclusion}

Travelling in Southern Italy, and publishing their experience on non-feminist periodicals, gives emancipatory identity opportunities to women, what travel in a beaten track and novels could not have supplied. "The genius loci was represented as lurking in secret precincts off the beaten track" (Buzard, 1993, p. 6), and the choice of experiencing adventurousness in a contested space, far from being "only a special kind of snobbery", 
(Pemble, 1987, p. 265) is rather a gesture of "self-distinction" (Buzard, 1993, p. 6), a means to publicly spread their model of an appropriate anti-Angel identity. Constrained by editorial restrictions imposed by periodicals, and determined to emancipate also rhetorical strategies, their travelogues consistently match the periodical dictates for honest, straightforward, instructive, and amusing travel narrations. If Southern Italy emerged as "an anti-image to Britain” (Walchester, 2007, p. 9), travellers also disrupt conventional stereotypes suggesting different reconfigurations of the landscape and people (ambiguities are never resolved) and, most importantly, of themselves, activating the opportunity to imagine another identity outside the restraints of Englishness. By dwelling on their choice of an anti-tourism destination and on the nature of their travel as "a leisure activity" (Korte, 2012, p. 159) they are able not only to reshape the iconic, static, and fragile angelic nature of the female subject but also to renegotiate the conventional ambivalence of Southern Italy disrupting some of the commonest stereotypes. By publishing in a non-feminist periodical they win credit to be socially accepted both as true travellers and authoritative authorial voices in travel writing.

\section{References}

Altik, R. D. (1998). The English common reader. Columbus: Ohio University Press.

Anonymous. (1827a, April 10). Letters from a lady from abroad. Sicily. The Kaleidoscope: Or, Literary and Scientific Mirror , 7(354), 325-326.

Anonymous. (1827b, April 17). Letters from a lady from abroad. Sicily. The Kaleidoscope: Or, Literary and Scientific Mirror, 7(355), 333-334.

Anonymous. (1827c, May 1). Letters from a lady from abroad. Sicily. The Kaleidoscope: Or, Literary and Scientific Mirror, 7(357), 349-350.

Anonymous. (1852, January). The lady traveller: Adventures of Madame Ida Pfeiffer. The Leisure Hour, 1, 69-73.

Arapoglou, E., Fodor, M., \& Nyman, J. (Eds.). (2014). Mobile narratives. Travel, migration, and transculturation. London: Routledge.

Beetham, M. (1989). Open and closed: The periodical as a publishing genre. Victorian Periodicals Review, 22(3), 96-100.

Bijon, B., \& Gâcon, G. (Eds.). (2009). In-between two worlds: Narratives by female explorers and travellers, 1850-1945. New York: Peter Lang.

Bohem, K. (Ed.). (2012). Bodies and things in the nineteenth-century literature and culture. New York: Palgrave Macmillan.

Borm, J. (2004). Defining travel: On the travel book, travel writing and terminology. In G. Hooper and T. Youngs (Eds.), Perspectives on travel writing (pp. 13-26). Aldershot: Ashgate.

Brake, L., \& Demoor, M. (Eds.). (2011). Dictionary of nineteenth-century journalism. London: Academia Press and The British Library.

Brisson, U., \& Schweizer, B. (Eds.). (2009). Not so innocent abroad: The politics of travel and travel writing. Newcastle upon Tyne: Cambridge Scholars Publishing.

Buzard, J. (1993). The beaten track: European tourism, literature, and the ways to culture, 1800-1918. Oxford: Oxford University Press.

Clifford, J. (1997). Routes: Travel and translation in the late twentieth century. Cambridge, Massachusetts: Harvard University Press.

Dickie, J. (1999). Darkest Italy. The nation and stereotypes of the Mezzogiorno, 1860-1900. London: Macmillan.

Don Vann, J., \& VanArsdel, R. (Eds.). (1994). Victorian periodicals and Victorian society. Toronto: Scholar Press.

Douglas, M. (2000). Purity and danger. An analysis of the concepts of pollution and taboo. London: Routledge.

Doughan, D., \& Sanchez, D. (Eds.). (1987). Feminist periodicals 1855-1984. An annotated critical bibliography of British, Irish, commonwealth and international titles. Brighton: The Harvester Press.

Fanon, F. (1990). The wretched of the earth. Harmondsworth: Penguin Books.

Fraser, H., Green, S., \& Johnston, J. (Eds.). (2003). Gender and the Victorian periodical. Cambridge: Cambridge University Press. Gikandi, S. (1996). Maps of Englishness: Writing identity in the culture of colonialism. New York: Columbia University Press.

Gomez, T., \& Gifford, T. (Eds.). (2013). Women in transit through literary liminal spaces. Basingstoke: Palgrave Macmillan. 
Grant, J. A. (1872). Zanzibar. A review. Blackwood’s Edinburgh Magazine, 111, 691-708.

Johnson, P. C. (2014). Frameworks of freedom and fear: Authorizing the voice in women's travel writing. In G. R. Ricci (Ed.), Travel, discovery, transformation (pp. 101-122). New Brunswick: Transaction Publishers.

Hill, K. (Ed.). (2016). Britain and the narration of travel in the $19^{\text {th }}$ century. Farnham: Ashgate.

Houghton, W. E. (Ed.). (1989). The Wellesley index to British periodicals 1824-1900. Toronto: University of Toronto Press.

Kato, D. (2013). 'I write the truth as I see it:' Unsettling the boundaries of gender, travel writing and ethnography in Isabella Bird's Unbeaten tracks in Japan. In T. Gomez and T. Gifford (Eds.), Women in transit through literary liminal spaces (pp. 77-90). Basingstoke: Palgrave Macmillan.

Kennard, N. H. (1876, April). Taormina. Temple Bar, 52, 539-546.

Keppel, S. (1893, January). Byeways in Sicily. The National Review, 20, 661-667.

Korte, B. (2012). Travel writing in The English Woman's Journal (1858-1864): An area of leisure in the context of women's work. Victorian Periodicals Review, 45(2), 158-174.

Kuehn, J., \& Smethurst, P. (2009). Travel writing, form and empire. The poetics and politics of mobility. London: Routledge.

Ledbetter, K. (2009). British Victorian women's periodicals. Beauty, civilization and poetry. New York: Palgrave Macmillan.

Le Mesurier, Miss E. A. (1897, October). Calabrian sketches. Temple Bar, 112, 275-288.

Levine, P. (1990). “The humanising influences of five o'clock tea”: Victorian feminist periodicals. Victorian Periodicals Review, 33(2), 293-306.

Linton, L. E. (1884a, February). Bronte on Mount Etna. Temple Bar, 70, 229-241.

Linton, L. E. (1884b, June). The things of Palermo. To-Day, 1, 481-487.

Linton, L. E. (1884c, November). Some Sicilian customs. Temple Bar, 72, 393-404.

Melman, B. (1992). Women's orients: English women and the Middle East, 1718-1918. London: Macmillan.

Mills, S. (1991). Discourses of difference: An analysis of women's travel writing and colonialism. London: Routledge.

Ouditt, S. (2014). Impressions of Southern Italy. British travel writing from Henry Swinburne to Norman Douglas. London: Routledge.

Pemble, J. (1987). The Mediterranean passion. Victorians and Edwardians in the South. Oxford: Clarendon Press.

Ricci, G. R. (Ed.). (2014). Travel, discovery, transformation. New Brunswick (USA): Transaction Publishers.

Said, E. W. (1995). Orientalism. London: Penguin.

Saunders, C. B. (Ed.). (2014). Women, travel writing, and truth. London: Routledge.

Selléi, N., \& Waudby, J. (Eds). (2011). She’s leaving home. Women's writing in English in a European context. Bern: Peter Lang.

Tait, W. (1832, April). A Tête a tête with Mr. Tait. Tait’s Edinburgh Magazine, pp. 9-16.

Walchester, K. (2007). “Our Own Italy”. Nineteenth century women's travel writing and Italy. 1800-1844. Bern: Peter Lang.

Woolf, V. (1928). Virginia Woolf. On women and writing. Her essays, assessments and arguments. London: The Women's Press Ltd. 